\title{
IDENTIFIKASI DAN KARAKTERISTIK BAKTERI ASAM LAKTAT YANG DIISOLASI DARI VAGINA WANITA USIA SUBUR
}

\author{
Yessi Widya Putri', Andani Eka Putra², Bobby Indra Utama ${ }^{3}$
}

\begin{abstract}
Abstrak
Bakteri vagina adalah sumber utama dari laktat asam di vagina. Lactobacillus berperan memberikan proteksi pada sel epitelial vagina dengan memberikan bantuan pada hubungan antar sel serta sekresi bakteriosida berupa Hidrogen Perioksida $\left(\mathrm{H}_{2} \mathrm{O}_{2}\right)$. Lactobacillus sebagai mikroflora dominan vagina mampu menjaga $\mathrm{pH}$ vagina 4,5 sehingga dapat mengurangi risiko kolonisasi bakteri patogen. Peningkatan $\mathrm{pH}$ vagina menguntungkan bagi kelangsungan hidup Lactobacillus dan karakteristik Lactobacillus sebagai produk probiotik vagina. Penelitian ini bersifat deskriptif bertujuan mengetahui jenis bakteri asam laktat yang diisolasi dari vagina wanita usia subur dengan pemeriksaan makroskopis, mikroskopis, dan karakteristik molekuler. Populasi dari penelitian ini adalah wanita usia subur. Sampel penelitian ini sebanyak 39 orang. Teknik pengambilan sampel adalah consecutive sampling. Hasil penelitian didapatkan rata-rata umur responden 32 tahun, kelompok umur terbanyak $25-30$ tahun $(79,4 \%)$, rata-rata paritas responden adalah 2 orang, dan 2 diantara responden adalah wanita hamil. Dari 39 sampel setelah dilakukan pewarnaan Gram, didapatkan hampir semua isolat bakteri adalah bakteri Gram positif dengan bentuk kokus dan basil. Berdasarkan hasil identifikasi molekuler dengan analisis sekuensing didapatkan jenis Bakteri Asam Laktat, Lactobacillus crispatus, Lactobacillus oris, Lactobacillus salivarius, dan Enterococcus faecalis.
\end{abstract}

Kata kunci: Lactobacillus crispatus, Lactobacillus oris, Lactobacillus salivarius, Enterococcus faecalis, Bakteri Asam Laktat Vagina, Wanita Usia Subur

\begin{abstract}
Vaginal bacteria are the main source of lactic acid in the vagina. Lactobacillus acts to provide protection to vaginal epithelial cells by providing assistance in the intercellular relationship and bacteriocide secretion in the form of Hydrogen Perioxide (H2O2). Lactobacillus as the dominant vaginal microflora is able to maintain a vaginal pH of 4.5 so as to reduce the risk of pathogenic bacterial colonization. Increased vaginal $\mathrm{pH}$ is beneficial for the survival of Lactobacillus and the characteristics of Lactobacillus as a vaginal probiotic product. This research is descriptive in nature to find out the types of lactic acid bacteria isolated from the vagina of women of childbearing age by macroscopic, microscopic, and molecular characteristics. The population of this study were reproductive age women. The sample of this study was 39 people. The sampling technique was consecutive sampling. The results showed that the average age of respondents was 32 years, the highest age group was $25-30$ years (79.4\%), the average parity of respondents was 2 people, and 2 of the respondents were pregnant women. Of the 39 samples after Gram staining, almost all bacterial isolates were Gram positive bacteria with coccus and bacillary forms. Based on the results of molecular identification by sequencing analysis, Lactobacillus crispatus, Lactobacillus oris, Lactobacillus salivarius, and Enterococcus faecalis were found.
\end{abstract}

Keywords: Lactobacillus crispatus, Lactobacillus oris, Lactobacillus salivarius, Enterococcus faecalis, Lactat Acid Bacteria Vagina, reproductive age women

Affiliasi penulis: 1. Program Studi Magister S2 Biomedik FK UNAND (Fakultas Kedokteran Universitas Andalas), 2.Bagian Mikrobiologi FK UNAND, 3. Bagian Obstetri dan Ginekologi FK Unand.

Korespondensi : Yessi Widya Putri ${ }^{1}$, Andani Eka Putra ${ }^{2}$, Bobby Indra Utama ${ }^{3}$ email:Yessi_widyaputri@yahoo.com

Telp: $08127 \overline{6} 462209$

\section{PENDAHULUAN}

Mikroba di vagina adalah flora heterogen yang mengandung bakteri. Flora mikroba ini memainkan peran penting dalam pertahanan terhadap bakteri patogen. Pada vagina wanita sehat terdapat $95 \%$ ekosistem seimbang dari Lactobacilli. ${ }^{1}$

Lactobacillus merupakan spesies dominan dari mikroflora vagina dan beberapa bakteri aerobik dan anaerobik lainnya. Hubungan antara Laktobacillus vagina dan inangnya diatur oleh hormon yang menstimulasi sel epitel vagina untuk menghasilkan glikogen. Glikogen diubah menjadi asam laktat oleh Lactobacillus dan menghasilkan $\mathrm{pH}$ asam (<4.5) sehingga menghambat pertumbuhan bakieri patogen. ${ }^{2}$

Cairan vagina mengandung konsentrasi asam organik, peroksida dan polipeptida yang mendukung aktivitas melawan mikroba patogen. Lactobacilli menghasilkan bakteriosin, hidrogen peroksida dan asam organik yang menghambat pertumbuhan bakteri Grampositif dan Gram-negatif. Senyawa ini tidak hanya mengurangi jumlah sel bakteri, tetapi juga dapat mempengaruhi bakteri, metabolisme dan produksinya. Lactobacillus memproduksi peptida antimikroba yang disebut bacteriocins, yang penting pada mekanisme pertahanan terhadap mikroorganisme kompetitif. ${ }^{2}$

Bakteri asam laktat (BAL) adalah kelompok bakteri probiotik bersifat non patogen, menghasilkan asam laktat, kelompok jenis bakteri Gram positif, berbentuk coccus (bulat), atau bacillus (batang), tidak 
membentuk spora, katalase negatif dan oksidase positif, proses fermentasi menghasilkan asam laktat. ${ }^{3}$

Bakteri asam laktat mempunyai kemampuan menfermentasikan gula menjadi asam laktat, karena produksi asam laktat oleh BAL berjalan dengan cepat, maka pertumbuhan mikroba lain yang tidak diinginkan dapat terhambat. BAL adalah famili Lactobacillaceae yaitu Lactobacillus dan famili Streptococcaceae terutama Leuconostoc, Streptococcus dan Pediococcus. ${ }^{4}$

Pada wanita normal terdapat kolonisasi Lactobacillus yang mampu memproduksi $\mathrm{H}_{2} \mathrm{O}_{2}$ yang dapat menghambat pertumbuhan mikroba. Pada penderita vaginosis bacterial terjadinya penurunan jumlah populasi Lactobacillus secara menyeluruh, sedangkan populasi yang tersisa tidak mampu memproduksi $\mathrm{H}_{2} \mathrm{O}_{2}$. Sebaliknya bakteri anaerob tumbuh secara berlebihan sebagai akibat dari peningkatan substrat, peningkatan $\mathrm{pH}$, dan hilangnya flora normal Lactobacillus $s p .^{5}$

Beberapa spesies Lactobacillus (L. crispatus., $L$. gasseri., $L$. jensenii) memiliki peranan anti microbial terutama pada Coccus (Neisseriria gonorrhea) dengan cara meningkatkan $\mathrm{pH}$ vagina dan mensekresikan asam laktat. Dalam keadaan anaerob kelompok bakteri dari golongan Lactobacillus memiliki peranan penting dalam memberikan proteksi pada sel epitelial vagina dengan memberikan bantuan pada hubungan antar sel serta sekresi bakteriosida berupa hidrogen perioksida. ${ }^{6}$

Toleransi bakteri asam laktat yang cukup tinggi terhadap asam disebabkan bakteri tersebut mampu mempertahankan sitoplasma lebih alkali daripada $\mathrm{pH}$ ekstraseluler. Untuk mempertahankan $\mathrm{pH}$ sitoplasma lebih basa, sel harus memiliki membrane barrier yang membatasi pergerakan senyawa atau proton. Komposis asam lemak dan protein penyusun membaran yang beragam diantara spesies bakteri diduga mempengaruhi keragaman ketahanan bakteri terhadap $\mathrm{pH}$ yang rendah. ${ }^{7}$

Natrium klorida $(\mathrm{NaCl})$ atau garam dapur dapat membatasi pertumbuhan organisme pembusuk dan mencegah dari pertumbuhan sebagian organisme, namun bakteri tertentu masih dapat tumbuh dalam larutan garam tinggi. Garam mempunyai sifat bakteriosid (daya membunuh) dan bakteriostatik (daya menghambat). Aksi osmotic larutan garam bertindak sebagai membrane semipermiabel menurunkan kadar air sehingga menghambat kegiatan bakteriologis dan enzimatis. ${ }^{8}$

Efek menstruasi menurunkan kapasitas Lactobacillus, dengan menggunakan pewarnaan Gram didapatkan jumlah Lactobacillus berkurang. Efek dari hubungan seksual berdampak sedikit pada Lactobacillus, tetapi ada kenaikan jumlah dari koloni Enterococcus, E. Coli dan Streptococcus grup B setelah berhubungan seksual. Penggunaan douching vagina yang menggunakan antiseptik dan digunakan rutin dapat mengubah mikroflora vagina serta meningkatkan kejadian vaginitis akibat jamur. ${ }^{9}$

Lactobacillus rentan terhadap antibiotik Beta Lactamase seperti Amoksilin serta Cephalosporin yang sering digunakan untuk mengobati infeksi saluran genital, sedangkan antibiotik Doksisiklin tidak aktif melawan Lactobacillus. Antibiotik topical maupun oral metronidazole tidak menyebabkan efek negatif melawan Lactobacillus, tetapi menyebabkan peningkatan kolonisasi. Klindamisin krim yang digunakan untuk mengobatan vaginosis bacterial menyebabkan penurunan awal kolonisasi Lactobacillus, tetapi dapat meningkatkan kolonisasi Lactobacillus setelah pemakaian satu bulan. ${ }^{9}$

Proses proteksi yang dilakukan oleh flora normal telah di ketahui tidak hanya dengan mempertahankan keadaan asam pada vagina, sekresi hidrogen perioksida dan bakteriocin merupakan dua proses penting sebagai bioindikator proteksi dari bakteri patogen. Produksi hidrogen perioksida telah diketahui sebagai mekanisme yang bersifat antagonis terhadap bakteri, proses kerja hidrogen perioksida secara langsung menghambat mikroorganisme yang dengan pengaktifasian mieloperoksidase. ${ }^{10}$

Toksisitas $\mathrm{H}_{2} \mathrm{O}_{2}$ yang diproduksi oleh Lactobacilli dengan kehadiran katalase menghambat pertumbuhan $G$ vaginalis dan Bacteroides bivius. Namun, konsentrasi produksi $\mathrm{H}_{2} \mathrm{O}_{2}$ Lactobacilli harus dikombinasikan dengan myeloperoxidase dan klorida dalam lendir vagina agar menjadi toksik bagi bakteri $G$. vaginalis. ${ }^{11}$

Beberapa bakteri juga dijumpai pada vagina diantaranya kelompok coccus Gram positif seperti Atopobium vaginae, Peptostreptococcus spp, Staphylococcus spp, Streptococcus spp, Fusobacterium spp, Garnerella vaginalis, Mobiluncus, Prevotella spp dan kelompok mikroorganisme usus Gram negatif seperti Esherichia coli. ${ }^{12}$

Penelitian lain menyebutkan beberapa spesies bakteri yang di temukan pada vagina dan servik wanita cukup beragam, seperti Lactobacillus sp., Diptheroids., Sthapylococccus epidermidis., Sthapylococcus aureus., Bacterioides sp., Peptostrerptococcus sp., Eschercia coli., Candida albican., Gardnerella vaginalis., Stereptococcus agalactiae., Peptococcus sp., Clostridium sp., dan Proteus sp. ${ }^{13}$

\section{METODE}

Penelitian ini merupakan penelitian deskriptif, dilakukan di Laboratorium Mikrobiologi Fakultas Kedokteran Universitas Andalas. Sampel penelitian adalah wanita usia subur yang sudah menikah, tidak sedang menggunakan antibiotik dan tidak sedang menggunakan AKDR. Teknik pengambilan sampel dengan consecutive sampling yaitu setiap penderita yang memenuhi kriteria inklusi dimasukkan dalam subyek penelitian sampai jumlah sampel tercapai. Jumlah sampel penelitian sebanyak 39 sampel. Pemeriksaan mikroskopis dan makroskopis bakteri dilakukan diLaboratorium Fakultas kedokteran Universitas Andalas. Pemeriksaan molekuler dilakuan dengan mengidentifikasi bakteri dengan metode PCR konvensional dan dilanjutkan dengan sekuensing yang dikirim ke laboratorium FIRST BASE , 41 Science Park Rd. Singapura.

\section{HASIL}

Total sampel penelitian yang memenuhi kriteria inklusi serta telah disetujui oleh Komite Etika Penelitian Fakultas Kedokteran Andalas berjumlah 39 orang. Pasien 
diambil swab dinding vaginanya untuk selanjutnya dilakukan pemeriksaan mikroskopis, makroskopis dan molekuler. Penelitian ini dilakukan mulai November 2017 hingga Maret 2018.

Tabel 1. Karakteristik Sampel Penelitian

\begin{tabular}{lrl}
\hline Karakteristik & f & \% \\
\hline Umur & & \\
$25-34$ & 31 & 79,4 \\
$35-40$ & 4 & 10,3 \\
$>40$ & 4 & 10,3 \\
Paritas & & \\
Nullipara & 6 & 15,4 \\
Primipara & 10 & 25,6 \\
Multipara & 23 & 59 \\
Kontrasepsi & & \\
Hormonal & 4 & 10,3 \\
Non hormonal & 20 & 51,3 \\
$\begin{array}{l}\text { Alamiah } \\
\text { Tidak menggunakan kontrasepsi } \\
\text { (Hamil) }\end{array}$ & 13 & 33,3 \\
\hline
\end{tabular}

Pada penelitian ini didapatkan umur minimum responden adalah 25 tahun, umur maksimum responden adalah 44 tahun, rata-rata umur responden adalah 32 tahun dan kelompok umur terbanyak adalah kelompok umur $25-30$ tahun $(79,4 \%)$. Rata-rata paritas responden adalah 2 orang, dan 2 diantara responden adalah wanita hamil. Gambaran ini dapat dillihat pada tabel 1.

\section{Identifikasi Bakteri Asam Laktat Secara Makroskopis}

Pada penelitian ini jenis bakteri asam laktat yang ditemukan berdasarkan pemeriksaan makroskopis berbentuk bulat/bundar, berwarna putih, putih kekuningan, hingga coklat muda transparan dengan tepian licin, berombak, dan ada yang berbentuk rizoid, elevasi koloni bakteri yang ditemukan ada yang cembung, dan ada yang datar.

\section{Identifikasi Bakteri Asam Laktat Secara Mikroskopis}

Pada penelitian ini bakteri asam lakta diidentifikasi secara mikroskopis dengan menggunakan metode pewarnaan Gram. Dari 39 sampel setelah dilakukan pewarnaan Gram, didapatkan bahwa hampir semua isolat bakteri merupakan bakteri Gram positif berbentuk basil dan cocobasil.

\section{Identifikasi Bakteri Asam Laktat Secara Molekuler}

Pada penelitian ini dilakukan pemeriksaan molekuler dengan mengisolasi DNA bakteri dengan primer 16s RNA 63F/1387R dan primer 16s bact 338/bact 1525, dilanjutkan dengan pemeriksaan PCR dan Sekuensing.

\section{Hasil BLAST Sekuensing Bakteri Asam Laktat}

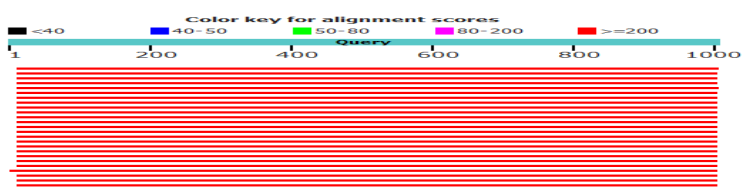

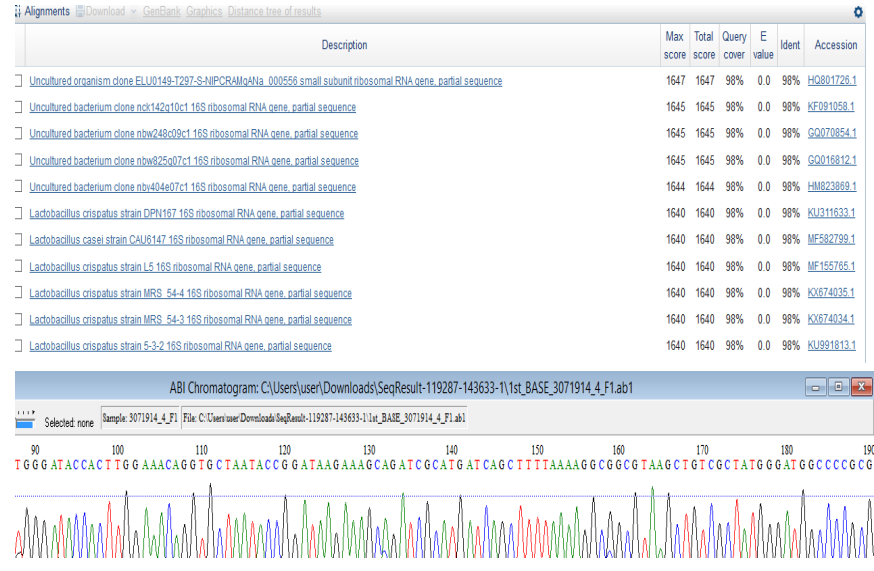

Tabel 2. Hasil BLAST Sekuensing Bakteri Asam Laktat

\begin{tabular}{ccc}
\hline No Isolat & Jenis Bakteri & Kemungkinan lain \\
\hline FV-33.3 & $\begin{array}{c}\text { Enterococcus } \\
\text { faecalis }\end{array}$ & $\begin{array}{c}\text { Enterococcus sp } \\
\text { L177(2011) 16S } \\
\text { ribosomal RNA gene }\end{array}$ \\
\hline FV-34.2 & $\begin{array}{c}\text { Lactobacillus } \\
\text { crispatus strain } \\
\text { DPN167 16S } \\
\text { Ribosomal RNA }\end{array}$ & $\begin{array}{c}\text { Lactobacillus caseii } \\
\text { strain CAU6147 16S } \\
\text { ribosomal RNA gene }\end{array}$ \\
\hline FV-42.3.1 & Lactobacillus Oris & Lactobacillus \\
& Strain L75 16S & Vaginalis gene for \\
& Ribosomal RNA & 16S rRNA sequence \\
& gene & clone SG3 \\
\hline FV-1.2 & Enterococcus & Enterococcus \\
& faecalis Strain & faecalis Strain \\
& QAUSD05 16S & QAUSD02 16S \\
& Ribosomal RNA \\
& gene & gene \\
& Lactobacillus & Lactobacillus \\
& Salivarius strain & Salivarius strain \\
& ZDY159a 16S & BCRC 14759 \\
FV-35.1 & Ribosomal RNA & chromosome \\
& gene & \\
& &
\end{tabular}

Berdasarkan hasil identifikasi molekuler dengan analisis sekuensing, didaptakn Bakteri Asam Laktat dari vagina wanita usia subur diantaranya adalah Lactobacillus crispatus,, Lactobacillus salivarius, Lactobacillus oris, Enterococcus faecalis.

\section{PEMBAHASAN}

Identifikasi bakteri asam laktat secara makroskopis dilakukan dengan memilih koloni yang diduga BAL berwarna putih kekuningan, berbentuk bulat dengan pinggiran licin. Warna koloni yang ditemukan antara lain berwarna putih, putih kekuningan, hingga coklat muda transparan. Tepian koloni ada yang berbentuk licin, berombak, dan ada yang berbentuk rizoid. Elevasi koloni bakteri yang ditemukan ada yang cembung, dan yang datar. Hal ini sesuai dengan teori yang mengatakan bahwa ciri dari koloni genus Lactobacillus yaitu koloni putih hingga kuning, bulat, bergelondong, permukaan tipis dan melebar dengan tepian licin pada agar miring yang digores. ${ }^{14}$

Identifikasi mikroskopis dilakukan dengan melakukan pewarnaan Gram pada koloni tunggal (single colony) bakteri. Bakteri Gram positif memiliki dinding sel yang tebal, membran sel selapis, serta tidak memiliki membaran luar, sedangkan bakteri Gram negatif 
mempunyai dinding sel yang tipis yang berada diantara dua lapis membaran sel. Pulasan Gram dalam pemeriksaan mikrobiologi diagnostik memungkinkan untuk klasifikasi cepat bakteri menjadi empat kategori sederhana : kokus Gram positif, basil Gram positif, kokus Gram negatif dan basil Gram negatif. ${ }^{15}$

Dengan pengecatan film bakteri mula-mula dilapisi dengan larutan zat warna karbol gentianviolet (karbol Kristal violet, karbolmetil violet) dan didiamkan beberapa lama, kemudian disiram dengan larutan iodium dan dibiarkan terendam dalam waktu yang sama. Sampai tingkat pengecatan ini selesai, semua bakteri akan berwarna ungu. Selanjutnya preparat didekolorisasi dengan alkohol atau campuran alkohol aseton sampai semua zat warna tampak luntur dari film. Setelah dicuci dengan air, preparat diberi warna kontras (counterstain) seperti safranin, karbolfuksin encer, air fuksin atau piromin B. ${ }^{16}$

Diantara berbagai macam bakteri yang dicat, ada yang dapat menahan zat warna ungu (metilviolet, kristalvisolet, gentianviolet) meskipun meskipun telah didekolorisasi dengan alkohol atau aseton. Bakteri yang memberi reaksi semacam ini dinamakan bakteri Gram positif. Sebaliknya, bakteri yang tidak dapat menahan zat warna setelah dekolorisasi dengan alkohol akan kembali menjadi tidak berwarna dan diberikan pengecatan dengan zat warna kontras, akan berwarna sesuai dengan zat warna kontras. Bakteri yang memperlihatkan rekasi semacam ini dinamakan bakteri Gram negatif. ${ }^{16}$

Teknik pewarnaan membagi bakteri berdasarkan perbedaan dasar dalam struktur dinding selnya. Bakteri Gram positif memiliki dinding sel seperti jala yang tebal yang terbuat dari peptidoglikan $(50-90 \%$ berat selubung sel), sedangkan bakteri gram negatif memiliki lapisan yang lebih tipis (10\% berat selubung sel). ${ }^{17}$

Pada penelitian ini hasil pewarnaan Gram pada 35 sampel yang diteliti, hampir seluruhnya merupakan bakteri Gram positif, yaitu ditandai dengan sel berwarna ungu setelah dilakukan pengecatan Gram. Hal tersebut dikarenakan bakteri asam laktat ini memiliki kandungan lipid yang rendah, sehingga dinding sel lebih mudah terdehidrasi akibat perlakuan alkohol yang menyebabkan pori-pori sel menjadi lebih kecil dan permeabilitasnya berkurang sehinggga zat warna kristal violet yang merupakan zat warna utama tidak dapat keluar dari sel. ${ }^{18}$

Penelitian ini sesuai dengan teori yang mengatakan bahwa BAL dari genus Lactobacillus merupakan bakteri Gram positif berbentuk batang, dengan ciri warna koloni putih susu atau krem, koloni bundar, berukuran 0,5-1,2 x 0,5-1,5 $\mu \mathrm{m}^{4}$

BAL adalah bakteri Gram positif, BAL genus Lactobacillus mempunyai bentuk batang, hampir kokoid umumnya berantai pendek dan berukuran 0,5 hingga $1,2 \times 1,0$ hingga10 $\mu \mathrm{m} .{ }^{14}$

Bakteri asam laktat adalah bakteri yang mampu memfermentasikan karbohidrat untuk memproduksi asam laktat dalam jumlah yang besar. Ciri-ciri bakteri asam laktat adalah bereaksi positif apada pewarnaan Gram, bereaksi negatif pada uji katalase, dan tidak membentuk spora. $^{19}$
Gen $16 S$ rRNA paling banyak digunakan sebagai penanda molekular untuk menentukan spesies bakteri. Kemiripan urutan basa nukleotida gen 16S rRNA digunakan sebagai "gold standard" untuk mengidentifikasi bakteri sampai ke tingkat speises. Ukuran gen $16 \mathrm{~S}$ rRNA sekitar 1500 basa. Ukuran gen 16S rRNA cukup memadai dan memudahkan dalam proses amplifikasi gen tersebut secara PCR dan sequencing. ${ }^{4}$

Analisis perbandingan urutan basa nukleotida dari gen-gen 16S rRNA digunakan untuk mengkonstruksi pohon fologenetik dan dapat diadikan sebagai pengklasifikasian makhluk hidup. Dengan demikian penggunaan analisis gen $16 \mathrm{~S}$ rRNA sebagai pendekatan untuk defenisi spesies secara molekular pada bakteri dapat menunjukkan hubungan kekerabatan. Metode klarifikasi secara molecular dapat menggambarkan hubungan kedekatan spesies. ${ }^{4}$

Flora normal pada wanita diantaranya kelompok dari genus Lactobacillus, seperti Lactobacillus crispatus dimana menghasilkan asam laktat yang memiliki fungsi perlindungan dalam melawan bakteri dari spesies patogenik. Mikroflora vagina mempunyai peranan mekanisme pertahanan yang paling penting untuk fungsi reproduksi, menjaga lingkungan yang sehat dan mencegah proliferasi mikroorganisme asing ke vagina. Lingkungan asam vagina, yang dikenal sebagai mekanisme pertahanan penting terhadap proliferasi patogen. ${ }^{2}$

Hasil penelitian lain pada wanita premenopause dan tidak dalam masa menstruasi, sampel diambil dengan swab, spesies yang ditemukan adalah Lactobacillus acidophilus, $L$. fermentum, $L$. gasseri, $L$. brevis, $L$. jensenii, L. casei dan L. delbrueckii. ${ }^{20}$

Penelitian lain menyebutkan flora dominan pada vagina ditemukan diantaranya Lactobacillus crispatus, Lactobacillus iners, Lactobacillus jesenii, Lactobacillus vaginalis, Lactobacillus caseii, Lactobacillus salivarius, Lactobacillus acidophilus, Lactobacillus brevis, Lactobacillus catenaforme, L. helveticus dan L. salivarius. Strain Lactobacillus ruminis, $L$. reuteri, $L$. oris dan $L$. Vaginalis. ${ }^{20}$.

Kehadiran dari Lactobacillus vagina dikaitkan dengan penurunan risiko vaginosis bakteri. Mekanisme antibakteri dengan penurunan $\mathrm{pH}$, produksi metabolit, seperti hidrogen peroksida dan asam laktat, dan molekul antibakteri, termasuk iocins bakteremia. Penelitian lain menyebutkan flora dominan dari vagina wanita adalah Lactobacillus spesies diantaranya $L$. inners, L. crispatus, L. gaserii, L. jeseii. ${ }^{21}$

Bakteri asam laktat adalah bakteri yang menghasilkan asam laktat dari glukosa, termasuk bakteri Gram-positif, kokus yang tidak berspora atau membentuk spora, kokobasil atau batang. Lactobacillus merupakan BAL yang berbentuk batang, sedangkan Leuconostoc, Enterococcus, Pediococcus, Lactococcus dan Streptococcus berbentuk kokus. ${ }^{22}$

Bakteri asam laktat dari genus Lactobacillus merupakan bakteri Gram positif, anaerob fakultatif, berbentuk batang $(0,5-1,5 \mu \mathrm{m}$ s/d 1,0-10 $\mu \mathrm{m})$, dan tidak bergerak (non motil). Genus Lactococcus mempunyai ciri- 
ciri morfologi warna koloni putih susu atau agak krem, bentuk koloni bundar atau bulat besar, sel berbentuk bola yang berukuran 0,5-1,2 x 0,5-1,5 $\mu \mathrm{m}$. Genus Enterococcus merupakan bakteri asam laktat Gram positif, berbentuk coccus (bulat), mesofilik, dan homofermentatif. ${ }^{4}$

Genus Enterococcus mempunyai kemampuan untuk menghasilkan katalase negatif, suhu untuk pertumbuhan bakteri ini adalah $10-45^{\circ} \mathrm{C}$ dan tumbuh baik pada $\mathrm{NaCl} 6,5 \%$. Menurut skema Identifikasi pada Bergey's manual of Determinative Bacteriology, Enterococcus merupakan bakteri Gram positif yang memiliki dinding sel, golongan 17: kokus gram-positif. ${ }^{23}$

Enterococcus faecalis merupakan bakteri yang tidak membentuk spora, tidak bergerak, mempunyai ukuran diameter 0,5-1 $\mu \mathrm{m}$, terdiri dari rantai pendek, berpasangan, atau bahkan tunggal. Dinding sel bakteri ini terdiri dari $40 \%$ peptidoglokan. Enterococcus faecalis adalah bagian dari flora usus normal. Enterococcus pada awalnya diklasifikasi sebagai Streptococcus Group $D$, karena mereka memiliki antigen dinding sel Grup D. Enterococcus juga mampu berkembang dalam kisaran $\mathrm{pH}$ $4,8-9,6 .{ }^{23}$

\section{SIMPULAN}

Jenis Bakteri Asam Laktat (BAL) yang ditemukan pada vagina wanita usia subur pada penelitian ini berdasarkan pemeriksaan molekuler diantaranya Lactobacillus crispatus, Lactobacillus oris , Lactobacillus salivarius, dan Enterococcus faecalis. Jenis bakteri asam laktat yang ditemukan berdasarkan pemeriksaan makroskopis berbentuk bulat/bundar, berwarna putih, putih kekuningan, hingga coklat muda transparan dengan tepian licin, berombak, dan ada yang berbentuk rizoid, elevasi koloni bakteri yang ditemukan ada yang cembung, dan yang datar. Jenis bakteri asam laktat yang ditemukan berdasarkan pemeriksaan mikroskopis setelah pewarnaan Gram adalah batang Gram positif dan coccus Gram positif.

\section{SARAN}

Disarankan kepada peneliti berikutnya untuk melakukan penelitian lebih lanjut terhadap Lactobacillus dengan membandingkan produksi asam laktat, hidrogen peroksida dan bakteriosin diantara Lactobacillus crispatus, Lactobacillus oris, Lactobacillus salivarius, sehingga dapat dijadikan kandidat sebagai probiotik kesehatan reproduksi wanita.

\section{DAFTAR PUSTAKA}

1. Amin M, Goodarzi H, Orang Z, Farsi S, Jorfi M. Isolation and Identification of Lactobacillus Species from the Vagina and Their Antimicrobial Properties, African Journal of Microbiology Research. 2011; 5(20). 3300-3304

2. Dasari S, Karanam S, Anandan, Rajendra W, Valluru L. Role of Microbial Flora in Female Genital Tract ; A Comprehensive Review. Asian Pacific Journal of Tropical Disease. 2016; 6(11):909-917.
3. Khalid K. An Overview of Lactid Acid Bacteria. International Journal of Biosciences (IJB). 2011; 1(3):1-13.

4. Syukur S, Purwati E, Bioteknologi Probiotik, Penerbit CV. Andi Offset. Yogyakarta; 2013. Hal.2-5

5. Prawirohardjo S, IImu Kandungan. Yayasan Bina Pustaka Sarwono Prawirohardjo. Jakarta; 2005. Hal.275

6. Graver MA, Wade JJ. The Role of Acidification in the Inhibition of Neisseria Gonorrhoeae by Vaginal Lactobacilli During Anaerobic Growth. Annals of Clinical Microbiology and Antimicrobials. 2011; 10:8.

7. Linharesn LM, Summers PR, Larsen B, Giraldo PC, Witkin S. Contemporary Perspectives on Vaginal $\mathrm{pH}$ and Lactobacilli. American Journal of Obstetrics \& Gynecology. 2011; 204(120):1-5.

8. Amalia, Dwijayanti RD, Haitami. Daya hambat $\mathrm{NaCl}$ Terhadap Pertumbuhan Staphylococcus Aureus, Medical Laboratory Technology Journal. 2016; 2(2):42-45.

9. Murtiastutik D. Buku Ajar Infeksi Menular Seksual. Surabaya: Airlangga University Press; 2008. HIm.34-35

10. Matu MN, Orinda GO, Njagi ENM, Cohen CR, Bukusi EA. In Vitro Inhibitory Activity of Human Vaginal Lactobacilli Against Pathogenic Bacteria Associated with Bacterial Vaginosis in Kenyan Women. Journal Anaerobe. 2009; 1-6.

11. Cribby S, Taylor M, Reid G. Vaginal Mikrobiota and The Use of Probiotics. Review Article Hindari Publishing Corporation Interdisciplinary Perspective on Infectious Diseases. 2008; 2008:1-9

12. Backer ED, Verhelst $R$, Verstraelen $H$, Alqumber MA, Burton JP, Tagg JR ,et al. Quantitative Determination by Real-time PCR of Four Vaginal Lactobacillus Species, Gardnerella vaginalis and Atopobium vaginae Indicates an Inverse Relationship Between L. gasseri and L. iners, BMC Microbiology. 2007; 7:115.

13. Ekanem El, Efiok EE, Udoh AE, Inyang OA. Study of The Bacterial Flora of the Vagina and Cervix in Women of, Childbearing Age in Rural Community of Niger Delta Region Nigeria. Ekanem et al. Gynecol Obstetric. 2012; 2:1

14. Soeharsono. Probiotik Basis IImiah, Aplikasi dan Aspek Praktis. Bandung: Widya Padjajaran; 2010. HIm.66-68

15. Elliot $\mathrm{T}$, Whorthington O, Gill, Mikrobiologi Kedokteran \& Infeksi. Jakarta: EGC; 2013. HIm.171

16. Irianto K. Mikrobiologi Menguak Dunia Mikroorganisme. Jilid 1. Bandung: Yrama Widya; 2006. HIm.59-61

17. Jawetz E, Melnick J, Adelberg EA. Mikrobiologi Kedokteran Edisi 25. Penerjemah Elferia RN. Jakarta: EGC; 2013. HIm.38-47.

18. Zahro F. Isolasi dan Identifikasi Bakteri Asam Laktat Asal Fermentasi Markisa Ungu (Pasiflora edulis var.Sims) Sebagai Penghasil Ekspolisakarida. [Skripsi]. Malang: Jurusan Biologi UIN Malang; 2014. HIm.51-52 
19. Ramadhan, Subagiyo, Margino S. Isolasi dan Karakteristik Bakteri Asam Laktat dari Usus udang Penghasil Bakteriosin sebagai Agen Antibakteria Pada Produk-Produk Penghasil Perikanan. Jurnal Saaintek Perikanan. 2012 8(1):42-52.

20. Pascual L, Ruiz F, Giordano W, Barberis IL. Vaginal Colonization and Activity of the Probiotic Bacterium Lactobacillus Fermentum L23 in a Murine Model of Vaginal Tract Infection. Journal of Medical Microbiology. 2010; 59:360-64.

21. Rebecca M, Brotman. Vaginal Microbiome and Sexually Transmittes Infections an Epidemiologic Perspective, J. Clin Invest. 2011; 121(12):4610 4617.

22. Todar K. Lactic Acid Bacteria. Review of Todar's Online Textbook of Bacteriology. "The Good, the Bad, and the Deadly". Science Magazine. 2012; 304:1421.

23. Jawetz E, Melnick J, Adelberg EA. Mikrobiologi Kedokteran Edisi 20. Penerjemah Nugroho E, Maulany RF. Jakarta: EGC; 1996. HIm.219-231. 